\title{
A Symmetrical Dirhenium(I) Complex with 4,4'-Azobis(2,2'-bipyridine) as a Bridging Ligand: Synthesis, Physicochemical Properties and Applications in Detection of Biologically Relevant Thiols and in Chemotherapy for Bone Cancer
}

\author{
Pedro O. Abate, ${ }^{a}$ Marco Sottile, ${ }^{b}$ Ignacio E. León, ${ }^{b}$ Mónica M. Vergara ${ }^{a}$ and Néstor E. Katz ${ }^{\circledR *, a}$ \\ ${ }^{a} I N Q U I N O A$ (UNT-CONICET), Instituto de Química Física, \\ Facultad de Bioquímica, Química y Farmacia, Universidad Nacional de Tucumán, \\ Ayacucho 471, T4000INI, San Miguel de Tucumán, Argentina \\ ${ }^{b}$ Centro de Química Inorgánica, CEQUINOR, (CONICET-UNLP), Facultad de Ciencias Exactas, \\ Universidad Nacional de La Plata, Bv 120 No. 1465, 1900 La Plata, Buenos Aires, Argentina
}

\begin{abstract}
A new dinuclear complex of formula $\left[\left\{\operatorname{Re}(\mathrm{CO})_{3}(\mathrm{py})\right\}_{2}(\mu-4,4\right.$ "'-azobpy $\left.)\right]\left(\mathrm{PF}_{6}\right)_{2}$, with py = pyridine and 4,4"-azobpy $=4,4$ "-azobis $(2,2$ '-bipyridine $)$, has been synthesized and characterized by spectroscopic and electrochemical techniques. The symmetrical nature of the dimetallic cation has been confirmed by nuclear magnetic resonance (NMR) measurements. When adding L-cysteine or L-glutathione, large and rapid changes in its UV-Vis absorption spectra were observed, which can be used for detecting both biologically relevant thiols. A promising activity for using this complex as a chemotherapeutic agent for bone cancer was also disclosed. Quantum mechanical calculations supported the experimental data.
\end{abstract}

Keywords: rhenium, thiol detection, chemotherapy

\section{Introduction}

Transition metal complexes with polypyridyl ligands containing the azo $(-\mathrm{N}=\mathrm{N}-)$ group have been widely studied for diverse applications in bioinorganic chemistry, such as sensing of biologically relevant thiols, ${ }^{1}$ cell imaging, ${ }^{2}$ photodynamic therapy ${ }^{3}$ and chemotherapy. ${ }^{4}$ In particular, tricarbonylrhenium(I) complexes with azobipyridines present synthetic versatility as well as thermal and photochemical stability, leading to their use as efficient probes for sensing or switching purposes. For example, we recently reported ${ }^{5}$ the preparation and properties of a symmetrical dinuclear complex of formula $\left[\left(\mathrm{CH}_{3} \mathrm{CN}\right)(\mathrm{CO})_{3} \operatorname{Re}(4,4\right.$ "'-azobpy $\left.) \operatorname{Re}(\mathrm{CO})_{3}\left(\mathrm{CH}_{3} \mathrm{CN}\right)\right]\left(\mathrm{PF}_{6}\right)_{2}$, with 4,4"-azobpy = 4,4"-azobis-(2,2'-bipyridine), which can be used for detecting L-cysteine (Cys) or as a molecular "switch" with a double proton-coupled electron transfer (PCET) process that occurs by adding a strong reductant such as dithionite. It must be emphasized that in this case the switching properties arise from an excited state centered on the reduced and protonated species derived

*e-mail: nkatz@fbqf.unt.edu.ar

Dedicated to Prof Henrique Eisi Toma on the occasion of his $70^{\text {th }}$ birthday. from 4,4"-azobpy, contrasting to the switching properties exhibited by complexes previously studied by Otsuki et al. ${ }^{6}$ based on excited states centered in auxiliary bpy ligands. A similar behavior as a "molecular switch" has been described in our recent work ${ }^{7}$ on the synthesis and properties of a mononuclear tetracyanoruthenium(II) complex coordinated to 4,4 "-azobpy.

Taking into account that if we replace $\mathrm{CH}_{3} \mathrm{CN}$ as auxiliary ligands by less $\pi$-accepting ligands such as py (pyridine) would improve the sensibility of detection and/or depletion of biologically relevant thiols, we report herein the synthesis, electrochemical and spectroscopic characterization, interactions with Cys and L-glutathione (GSH) and activity against osteosarcoma cell lines of a new dinuclear symmetrical complex of formula $\left[\left\{\operatorname{Re}(\mathrm{CO})_{3}(\mathrm{py})\right\}_{2}(\mu-4,4\right.$ "-azobpy $\left.)\right]\left(\mathrm{PF}_{6}\right)_{2}$ or $(\mathbf{1})\left(\mathrm{PF}_{6}\right)_{2}$, whose structure is shown in Scheme 1.

\section{Experimental}

Materials and techniques

All chemicals used in this work were analyticalreagent grade and used without further purification. 


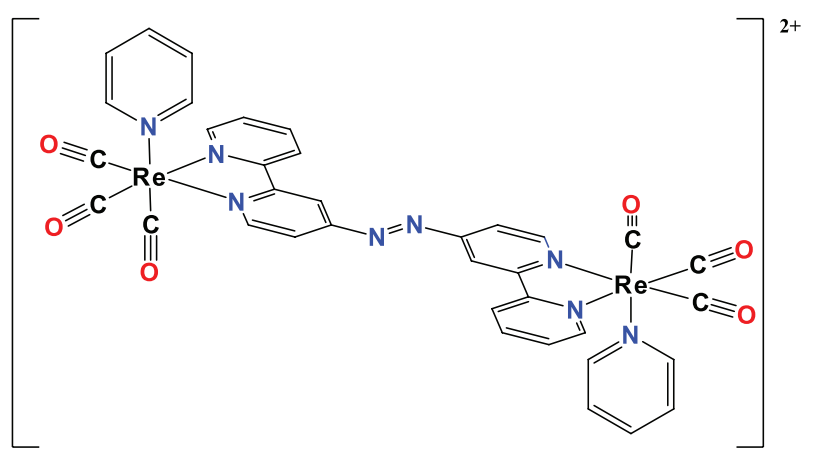

Scheme 1. Structure of complex 1.

$\mathrm{Re}(\mathrm{CO})_{5} \mathrm{Cl}, \mathrm{Ag}\left(\mathrm{CF}_{3} \mathrm{SO}_{3}\right)$ and $\mathrm{GSH}$ were purchased from Aldrich (St. Louis, MO, USA) and Cys from Fluka (München, Germany). 4,4"-Azobpy and $\left[\left\{\operatorname{Re}(\mathrm{CO})_{3}(\mathrm{Cl})\right\}_{2}(\mu-4,4 "\right.$-azobpy $\left.)\right]$ were synthesized as previously reported. ${ }^{5} \mathrm{CH}_{3} \mathrm{CN}$ was freshly distilled over $\mathrm{P}_{4} \mathrm{O}_{10}$ for electrochemical measurements. Tetrakis (n-butyl) ammonium-hexafluorophosphate (TBAH) was dried at $150{ }^{\circ} \mathrm{C}$ for $24 \mathrm{~h}$ before being used as supporting electrolyte in electrochemical measurements. UV-Visible (UV-Vis) spectra were recorded on a Varian Cary 50 spectrophotometer, using 1-cm quartz cells. Infrared (IR) spectra were obtained as $\mathrm{KBr}$ pellets with a PerkinElmer Spectrum RX-I FTIR spectrometer. Cyclic voltammetry (CV) and differential pulse voltammetry (DPV) measurements were carried out in Ar-saturated solutions at a scan rate of $100 \mathrm{mV} \mathrm{s}^{-1}$ by using a BAS Epsilon EC equipment, with vitreous $\mathrm{C}$ as working electrode, $\mathrm{Pt}$ wire as auxiliary electrode, and $\mathrm{Ag} / \mathrm{AgCl}(3 \mathrm{M} \mathrm{NaCl})$ as reference electrode. Nuclear magnetic resonance (NMR) spectra were obtained in $\mathrm{CD}_{3} \mathrm{CN}$ with a Bruker $300 \mathrm{MHz}$ instrument operating at a frequency of $300.13 \mathrm{MHz}$ for ${ }^{1} \mathrm{H}$ NMR and $75.47 \mathrm{MHz}$ for ${ }^{13} \mathrm{C}$ NMR spectroscopy. Mass spectra (MS) were recorded at CIBION (Buenos Aires, Argentina) using a QTOF mass spectrometer from Waters Corporation (USA). Chemical analyses were carried out at INQUISUR (Bahía Blanca, Argentina) with an estimated error of $\pm 0.4 \%$, using a CHN Elemental Analyzer CE-440 from Exeter Analytical (UK).

\section{Computational procedures}

Density functional theory (DFT) calculations were carried out with the Gaussian 03 program package. ${ }^{8}$ Molecules were optimized using the PBE1PBE hybrid functional, which is composed of the Perdew, Burke and Ernzerhof exchange, and a correlation functional with $25 \%$ HF exchange. ${ }^{9}$ The basis set LanL2DZ was chosen for Re and $6-31 G^{*}$ for all other atoms. No symmetry restrictions were placed on the geometry optimizations. Frequency calculations were performed in all optimizations to ensure that these geometries corresponded to global minima. To include solvent polarization effects, all calculations were done by using the conductor-like polarizable continuum model (CPCM) with water as solvent. The contribution of different groups on the molecular orbitals were obtained using the GaussSum program, version 2.2. ${ }^{10}$

\section{Cell line and growth conditions}

Human osteosarcoma cell line (MG-63) was grown in Dulbecco's modified Eagle's medium (DMEM) containing $10 \%$ fetal bovine serum (FBS), $100 \mathrm{IU} \mathrm{mL}^{-1}$ penicillin and $100 \mu \mathrm{g} \mathrm{mL} \mathrm{m}^{-1}$ streptomycin at $37^{\circ} \mathrm{C}$ in $5 \%$ of $\mathrm{CO}_{2}$ atmosphere. This cell line was grown in a $75 \mathrm{~cm}^{2}$ flask until reaching $70-80 \%$ of confluence. Then, the cells were subcultured using TrypLE TM. For experiments, cells were grown in multi-well plates. The number of cells were 20,000 cells well ${ }^{-1}$. DMEM and TrypLE TM were purchased from Gibco (Gaithersburg, MD, USA), and FBS was purchased from Internegocios (Buenos Aires, Argentina). After 24 h, the monolayers were washed with DMEM and incubated under different conditions according to the experiments. Tissue culture materials were purchased from Corning (Princeton, NJ, USA). Control experiments using the rhenium precursor and the bridging ligand could not be done due to their extreme insolubility in water and organic solvents.

Cell viability: 3-(4,5-dimethylthiazol-2-yl)-2,5-diphenyltetrazolium bromide assay

The 3-(4,5-dimethylthiazol-2-yl)-2,5-diphenyltetrazolium bromide (MTT) assay was performed according to Mosmann. ${ }^{11}$ Briefly, cells were seeded in a 96-well dish, allowed to attach for $24 \mathrm{~h}$, and treated with different concentrations of 1 and cisplatin at $37^{\circ} \mathrm{C}$ for $24 \mathrm{~h}$. A stock solution of the complex $(20 \mathrm{mM}$ in dimethyl sulfoxide (DMSO)) was prepared which was transferred in aliquots to the culture aqueous media up to a maximum concentration $0.1 \mathrm{mM}$ of $\mathbf{1}$ with no dissolution problems, thus confirming the hypothesis of its high solubility in water, stated in the Introduction section. Besides, cisplatin was dissolved using a $0.9 \% \mathrm{NaCl}$ solution. Afterwards, the medium was changed and the cells were incubated with $0.5 \mathrm{mg} \mathrm{mL}^{-1}$ MTT under normal culture conditions for $3 \mathrm{~h}$. Cell viability was marked by the conversion of the tetrazolium salt MTT to a colored formazan by mitochondrial dehydrogenases. Color development was measured spectrophotometrically with a microplate reader (multiplate reader multiskan FC, Thermo Scientific) at $\lambda=570 \mathrm{~nm}$ after cell lysis in DMSO (100 $\mu \mathrm{L}$ per well). Cell viability was plotted as the percentage of the control value. 


\section{Statistical methods}

At least three independent experiments were performed for each experimental condition. Results are expressed as percentage $(\%)$ of basal and represent the mean \pm standard error of the mean (SEM). Statistical differences were analyzed using the Student's test.

Preparation of $\left[\left\{\operatorname{Re}(\mathrm{CO})_{3}(\mathrm{py})\right\}_{2}(\mu-4,4\right.$ "-azobpy $\left.)\right]\left(\mathrm{PF}_{6}\right)_{2} \cdot 8 \mathrm{H}_{2} \mathrm{O}$, (1) $\left(\mathrm{PF}_{6}\right)_{2} \cdot 8 \mathrm{H}_{2} \mathrm{O}$

$66 \mathrm{mg}(0.070 \mathrm{mmol})$ of the precursor $\left[\left\{\operatorname{Re}(\mathrm{CO})_{3} \mathrm{Cl}\right\}_{2}(4,4\right.$ "-azobpy) $]$, prepared as described before, ${ }^{5} 36 \mathrm{mg}(0.137 \mathrm{mmol})$ of $\mathrm{Ag}\left(\mathrm{CF}_{3} \mathrm{SO}_{3}\right)$ and $30 \mathrm{~mL}$ of a mixture of $\mathrm{CH}_{3} \mathrm{OH}: 1,4$-dioxane 1:2 (v/v) were placed in a $50 \mathrm{~mL}$ round bottomed flask and refluxed for $3 \mathrm{~h}$ in the dark. One drop of pyridine was then added to the mixture and the reflux was kept for another $3 \mathrm{~h}$. After cooling, the formed $\mathrm{AgCl}$ was filtered. The filtrate was evaporated to dryness, re-suspended in $1 \mathrm{~mL}$ of $\mathrm{CH}_{3} \mathrm{OH}$, and precipitated with $\mathrm{NH}_{4} \mathrm{PF}_{6}\left(0.4 \mathrm{~g}\right.$ in $2.5 \mathrm{~mL}$ of $\left.\mathrm{H}_{2} \mathrm{O}\right)$. The mixture was kept at $5^{\circ} \mathrm{C}$ for $6 \mathrm{~h}$ and filtered. The orange solid was washed with cold $\mathrm{H}_{2} \mathrm{O}(3 \times 10 \mathrm{~mL})$ and diethyl ether $(2 \times 10 \mathrm{~mL})$. The obtained orange solid was dried under vacuum over $\mathrm{P}_{4} \mathrm{O}_{10}$ for 24 h. Yield: $60 \mathrm{mg}$ (64.6\%). Anal. for $\mathrm{C}_{36} \mathrm{H}_{40} \mathrm{~N}_{8} \mathrm{O}_{14} \mathrm{P}_{2} \mathrm{~F}_{12} \mathrm{Re}_{2}$, experimental (calcd.): C, 29.2 (29.4); H, 1.7 (2.7); N, 7.5 (7.6); IR (KBr) v / cm ${ }^{-1} 2034,1921,1608,1474,1448,841$, 558; ${ }^{1} \mathrm{H}$ NMR (300.13 MHz, CD 3 CN) $\delta 9.49(\mathrm{~d}, 2 \mathrm{H}, J 5.9 \mathrm{~Hz}$, $\left.\mathrm{H}_{\mathrm{i}}\right), 9.28\left(\mathrm{~d}, 2 \mathrm{H}, J 5.9 \mathrm{~Hz}, \mathrm{H}_{\mathrm{a}}\right), 8.81\left(\mathrm{~d}, 2 \mathrm{H}, J 2.0 \mathrm{~Hz}, \mathrm{H}_{\mathrm{g}}\right)$, $8.55\left(\mathrm{~d}, 2 \mathrm{H}, J 8.2 \mathrm{~Hz}, \mathrm{H}_{\mathrm{d}}\right), 8.35\left(\mathrm{td}, 2 \mathrm{H}, J 7.9,1.5 \mathrm{~Hz}, \mathrm{H}_{\mathrm{c}}\right)$, $8.30\left(\mathrm{dd}, 4 \mathrm{H}, J 6.6,1.2 \mathrm{~Hz}, \mathrm{H}_{\mathrm{k}}\right), 8.14(\mathrm{dd}, 2 \mathrm{H}, J 6.0,1.9 \mathrm{~Hz}$, $\mathrm{H}_{\mathrm{j}}$ ), 7.87 (t, 4H, J 6.8 Hz, $\left.\mathrm{H}_{\mathrm{m}}\right), 7.32$ (dd, 4H, J 7.6, 6.4 Hz, $\left.\mathrm{H}_{1}\right) ;{ }^{13} \mathrm{C}$ NMR $\left(75.47 \mathrm{MHz}, \mathrm{CD}_{3} \mathrm{CN}\right) \delta 159.5,159.4,157.1$, 156.1, 155.1, 153.0, 142.3, 140.9, 130.4, 127.7, 126.2, 120.6, 119.4, 121.1; high-resolution MS (HRMS) $m / z$, calcd. for $\mathrm{C}_{36} \mathrm{H}_{24} \mathrm{~N}_{8} \mathrm{O}_{6} \mathrm{Re}_{2}[\mathrm{M}]^{2+}:$ 518.0453, found: 518.0452; calcd. for $\left[\mathrm{M}+\mathrm{PF}_{6}\right]^{+}:$1181.0535, found: 1181.0548 .

\section{Results and Discussion}

\section{Synthesis}

For preparing the $\mathrm{PF}_{6}^{-}$salt of $\mathbf{1}$, previously reported methods $s^{5,12,13}$ were followed, with slight modifications and no need of chromatographic separations. Introduction of py as an auxiliary ligand increases the solubility of the complex in aqueous solutions respect to that of the previously studied ${ }^{5}$ complex with $\mathrm{CH}_{3} \mathrm{CN}$, a relevant property to be considered for applications in sensing of thiols and activity against osteosarcoma cells. Although single crystals for X-ray diffraction analysis of this complex could not be obtained, its purity was assessed by elemental CHN analyses, NMR spectra and HRMS measurements, as disclosed in the Experimental section.

\section{UV-Vis spectrum}

Figure 1 shows the UV-Vis absorption spectrum of $\mathbf{1}$ in $\mathrm{H}_{2} \mathrm{O}$. Exact positions of the bands were inferred from deconvolution procedures. The bands at $\lambda_{\max }=260 \mathrm{~nm}$ (molar absorptivity $\varepsilon=4.1 \times 10^{4} \mathrm{M}^{-1} \mathrm{~cm}^{-1}$ ) and $\lambda_{\max }=280 \mathrm{~nm}$ ( $\varepsilon=3.8 \times 10^{4} \mathrm{M}^{-1} \mathrm{~cm}^{-1}$ ) can be assigned to intraligand (IL) transitions of the bridging ligand 4,4"-azobpy, as reported ${ }^{5}$ before for the $\mathrm{CH}_{3} \mathrm{CN}$ analogue. The band at $\lambda_{\max }=337 \mathrm{~nm}$ $\left(\varepsilon=1.5 \times 10^{4} \mathrm{M}^{-1} \mathrm{~cm}^{-1}\right)$ can be assigned to a metal-ligandto-ligand charge transfer (MLLCT) $\mathrm{d}_{\pi}(\mathrm{Re}) \rightarrow 4,4$ "-azobpy transition that occurs from the HOMO (highest occupied molecular orbital) which is mainly localized on the metallic center (with a significant contribution from the carbonyl groups) to the LUMO +1 (lowest occupied molecular orbital +1 ) which has a major contribution of the bpy rings, as discussed in the analogous $\mathrm{CH}_{3} \mathrm{CN}$ complex. ${ }^{5} \mathrm{~A}$ second band at $\lambda_{\text {max }}=412 \mathrm{~nm}\left(\varepsilon=1.2 \times 10^{4} \mathrm{M}^{-1} \mathrm{~cm}^{-1}\right)$ can be observed and assigned to an MLLCT d $\mathrm{d}_{\pi}(\mathrm{Re}) \rightarrow 4,4$ "-azobpy transition, from the HOMO to the LUMO, that has a major contribution from the azo group of the bridging ligand. These assignments are further supported by results of DFT calculations shown below. UV-Vis spectra do not change in $\mathrm{CH}_{3} \mathrm{CN}$, as expected for tricarbonylrhenium(I) complexes.

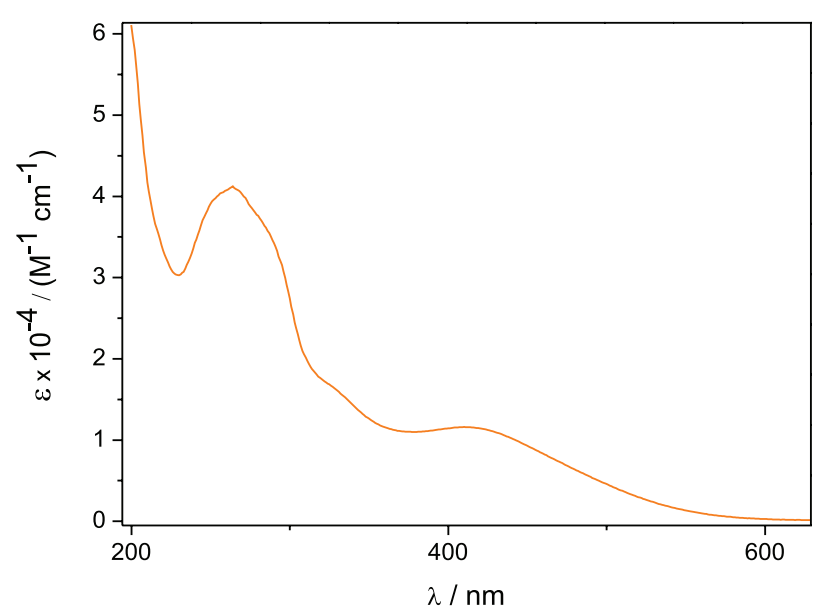

Figure 1. UV-Vis spectrum of $\mathbf{1}$ in $\mathrm{H}_{2} \mathrm{O}$ at room temperature.

IR spectrum

The IR spectrum of $\mathbf{1}$ is shown in Figure 2. The characteristic $v_{(\mathrm{C} \equiv 0)}$ stretching frequencies of the tricarbonylrhenium(I) moieties are detected at 2034 and $1921 \mathrm{~cm}^{-1}$ and can be assigned to $\mathrm{A}^{\prime}(1)$ and $\mathrm{A}^{\prime}(2)$ 
symmetries, respectively, ${ }^{5}$ in consistency with a facial configuration of the carbonyl ligands bonded to Re. The band of symmetry A" at $1936 \mathrm{~cm}^{-1}$ is barely seen as a shoulder of the band at $1921 \mathrm{~cm}^{-1}$ when the IR spectrum is amplified. The lower value observed for the stretching frequency of mode $\mathrm{A}^{\prime}(1)$ in complex $\mathbf{1}$ vs. its analogue with $\mathrm{CH}_{3} \mathrm{CN}\left(v_{(\mathrm{C}=\mathrm{O})}=2039 \mathrm{~cm}^{-1}\right)^{5}$ indicates an increase in $\pi$-backbonding from $\mathrm{Re}^{\mathrm{I}}$ to the carbonyls in $\mathbf{1}$. The intense bands at 841 and $558 \mathrm{~cm}^{-1}$ correspond to the stretching and deformation modes of the P-F bonds of the anion $\mathrm{PF}_{6}^{-}$, respectively. Due to the symmetrical structure of the complex, the $-\mathrm{N}=\mathrm{N}-$ stretching band could not be observed.

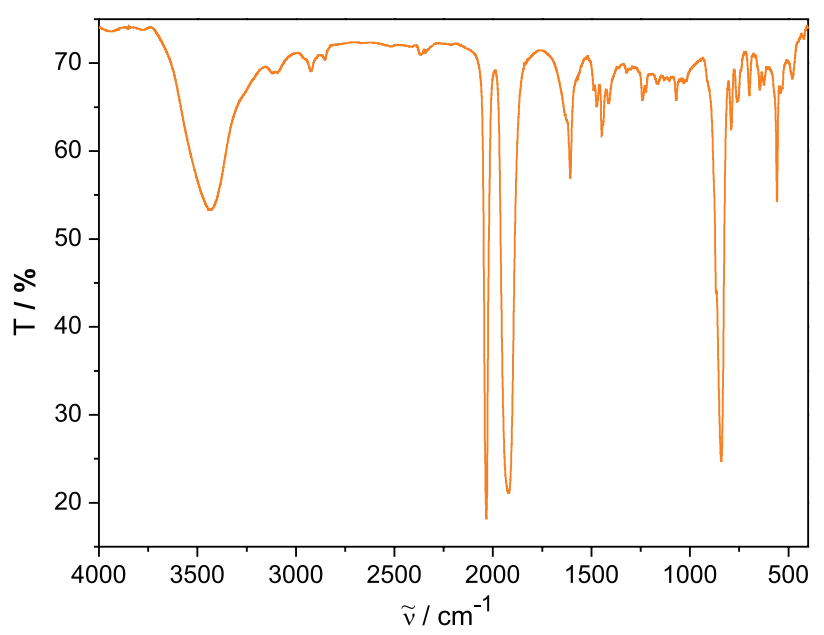

Figure 2. IR spectrum $\left(\mathrm{KBr}\right.$ pellet) of $(\mathbf{1})\left(\mathrm{PF}_{6}\right)_{2}$.

\section{NMR spectra}

Figure 3 shows the ${ }^{1} \mathrm{H}$ NMR spectrum of 1 in $\mathrm{CD}_{3} \mathrm{CN}$, which confirms the identity and purity of the complex. A complete structure elucidation could be accomplished with the aid of two-dimensional NMR techniques such as correlation spectroscopy (COSY), ${ }^{13} \mathrm{C}$ heteronuclear single quantum correlation (HSQC) and ${ }^{13} \mathrm{C}$ heteronuclear multiple bond correlation (HMBC) (Figures S1 to S4, Supplementary Information (SI) section). Due to the symmetrical nature of the complex, the ${ }^{1} \mathrm{H}$ NMR spectrum shows a set of 9 signals, which are assigned to the aromatic protons of 4,4"-azobpy and py. Since there are 10 non-equivalent protons, as shown in the inserted scheme in Figure 3, a set of 10 signals would be expected; however, the peak centered at $\delta=7.87 \mathrm{ppm}$ integrates for four protons, indicating the overlapping of the signals of two protons from py with two protons from 4,4 "'-azobpy.

\section{Electrochemistry}

The redox potentials of $\mathbf{1}$ were determined by $\mathrm{CV}$ and
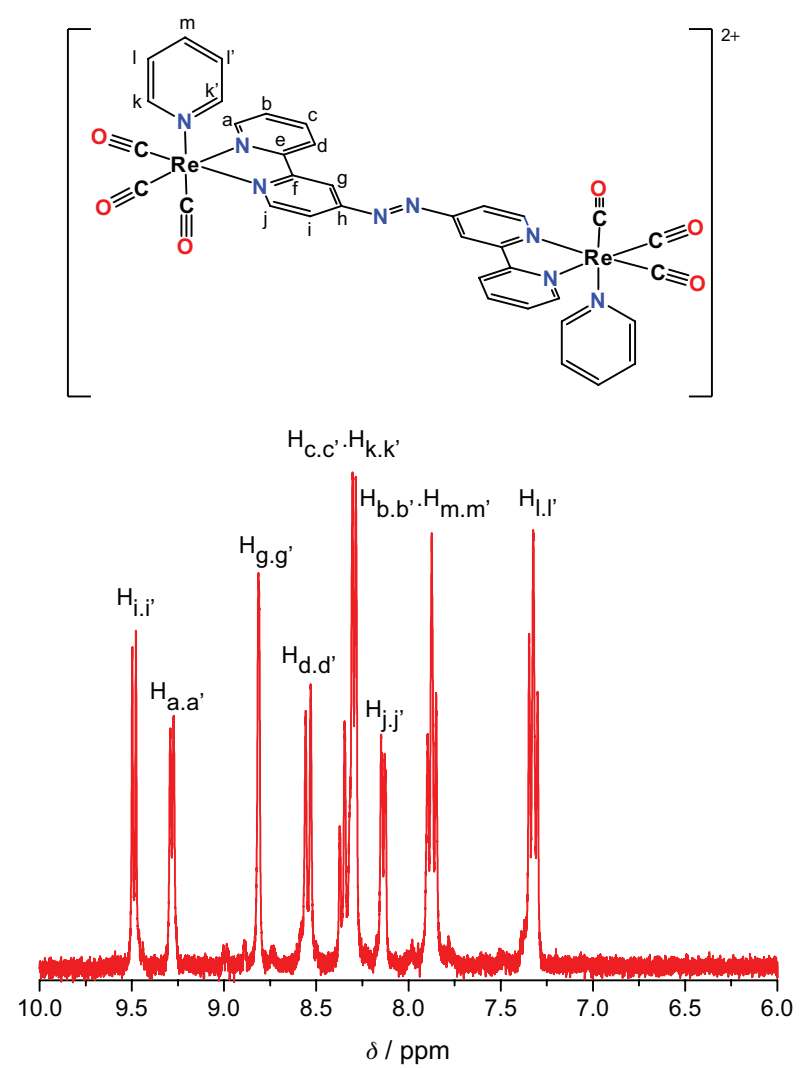

Figure 3. ${ }^{1} \mathrm{H}$ NMR spectrum of (1) (300.13 $\left.\mathrm{MHz}, \mathrm{CD}_{3} \mathrm{CN}\right)$ with their assignments.

DPV in $\mathrm{CH}_{3} \mathrm{CN}$ (0.1 M TBAH) at r.t. (room temperature) and referred vs. $\mathrm{Ag} / \mathrm{AgCl}$. Redox processes cannot be assigned to the solvent, as deduced from the baseline shown in Figure 4a. The scans were started at $0.2 \mathrm{~V}$ to avoid the break of the voltammograms near $0 \mathrm{~V}$. As displayed in Figure $4 \mathrm{~b}$, six redox processes can be detected by both electrochemical techniques. In the oxidative region of the $\mathrm{CV}$, the $\mathrm{Re}^{2+/+}$ redox couple exhibits a potential of $\mathrm{E}_{1 / 2}=1.84 \mathrm{~V}$, a value slightly lower than that observed for the $\mathrm{CH}_{3} \mathrm{CN}$ analogue. ${ }^{5}$ In the DPV, a small splitting (of $70 \mathrm{mV}$ ) is observed for both $\mathrm{Re}^{2+/+}$ redox couples of $\mathbf{1}$ at $\mathrm{E}_{1 / 2}=1.75$ and $1.82 \mathrm{~V}$, indicating a small delocalization in the corresponding mixed-valent species. In the reductive region, five additional waves can be observed by both techniques at $\mathrm{E}_{1 / 2}=-0.06,-0.38,-1.50,-1.76$ and $-1.92 \mathrm{~V}$, which are assigned to the redox processes $\mathrm{azo}^{0 /-1}, \mathrm{azo}^{-1 /-2}, \mathrm{bpy}^{0 /-1}$, bpy $^{-1 / 2}$, bpy $^{-2 /-3}$, respectively, in agreement with previous assignments, supported by UV-Vis spectroelectrochemistry and DFT calculations for the reduced species, of the analogous species of formula $\left[\left(\mathrm{CH}_{3} \mathrm{CN}\right)(\mathrm{CO})_{3} \operatorname{Re}(4,4 \text { "'-azobpy }) \operatorname{Re}(\mathrm{CO})_{3}\left(\mathrm{CH}_{3} \mathrm{CN}\right)\right]^{2+} .{ }^{5}$

Redox reactions with thiol-containing amino acids

Detection of biologically relevant amino acids with thiol 

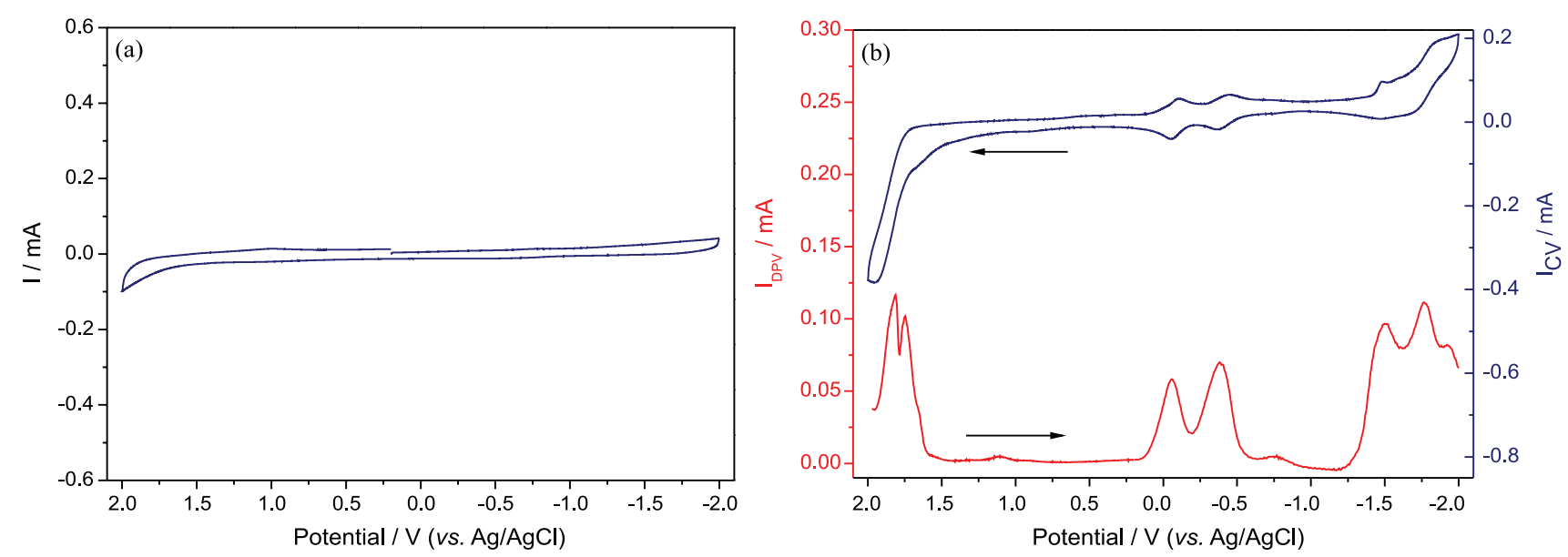

Figure 4. (a) Baseline voltammogram; (b) $\mathrm{CV}$ (blue curve) and DPV (red curve) of $\mathbf{1}$ in $\mathrm{CH}_{3} \mathrm{CN}, 0.1 \mathrm{M}$ TBAH.

groups, such as Cys and GSH, is important considering that these molecules are involved in the control of cellular oxidative stress. For example, it has been observed that GSH is overexpressed in cancer cells, a fact that increases the tumor cell resistance to oxidative stress. ${ }^{3}$ Dirhenium tricarbonyl complexes with 4,4"-azobpy as a bridging ligand are interesting systems for Cys or GSH detection and/or cellular depletion, since the inclusion of two rhenium centers in the complex structure has a dramatic effect on the redox potentials of the azo couples; for $\mathbf{1}$, the first reductive wave in $\mathrm{CV}$ is detected at $\mathrm{E}_{1 / 2}=-0.06 \mathrm{~V}$ ( $v s . \mathrm{Ag} / \mathrm{AgCl}$ ), while, for the similar bridged diruthenium species of formula $\left[(\text { bpy })_{2} \mathrm{Ru}(4,4 \text { "'-azobpy }) \mathrm{Ru}(\mathrm{bpy})_{2}\right]^{4+}$, the same process is detected at $\mathrm{E}_{1 / 2}=-0.59 \mathrm{~V}(v s . \mathrm{Ag} / \mathrm{AgCl}){ }^{6}$ Comparison with rhenium monomers was not accomplished since they could not be obtained. This value is even higher than the first reductive wave for the dirhenium analogue of formula $\left[\left(\mathrm{CH}_{3} \mathrm{CN}\right)(\mathrm{CO})_{3} \mathrm{Re}(4,4\right.$ "-azobpy) $\left.\operatorname{Re}(\mathrm{CO})_{3}\left(\mathrm{CH}_{3} \mathrm{CN}\right)\right]^{2+}$, with $\mathrm{E}_{1 / 2}=-0.12 \mathrm{~V}(v s . \mathrm{Ag} / \mathrm{AgCl}),{ }^{5}$ thus confirming that py is less $\pi$-accepting ligand than

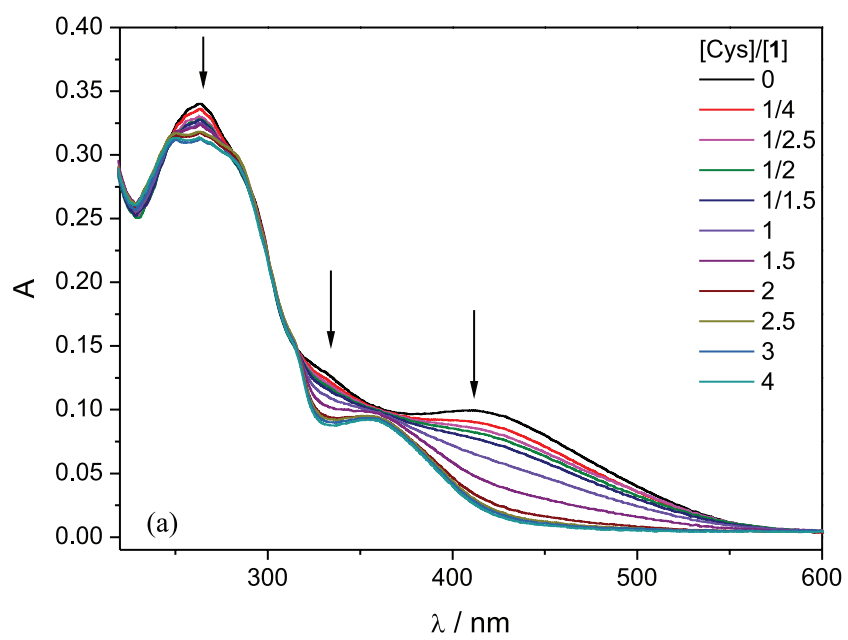

$\mathrm{CH}_{3} \mathrm{CN}$, as mentioned in the Introduction section. A rapid reaction of $\mathbf{1}$ with Cys and GSH is therefore expected, as confirmed by following the changes of UV-Vis spectra with addition of both thiols, shown in Figure 5. The bands at $\lambda_{\max }=412$ and $350 \mathrm{~nm}$ disappear, while new bands appear at $\lambda_{\max }=360 \mathrm{~nm}$ when both amino acids interact with $\mathbf{1}$, reactions which are completed within mixing time with a stoichiometric ratio of 2:1 [thiol]/[1], indicating a double reduction and double protonation of the azo $(-\mathrm{N}=\mathrm{N}-)$ group to give an hydrazo $(-\mathrm{HN}-\mathrm{NH}-)$ group in the bridging ligand. This assertion is supported by detection of the $-\mathrm{NH}$ proton signal at $\delta=7.07 \mathrm{ppm}$ in the ${ }^{1} \mathrm{H}$ NMR spectra of the reduced and protonated product (1H2) (Figure S5, SI section) and the disappearance of the two azo reduction couples in presence of a twofold excess of [L-Cys] over [1] (Figure S6, SI section). Selectivity was not tested in this study, although amino acids without thiol groups are not expected to react with $\mathbf{1}$. Calibration curves (Figure S7, SI section) for the thiol-containing amino acids studied here give limits of detection in the micromolar range.

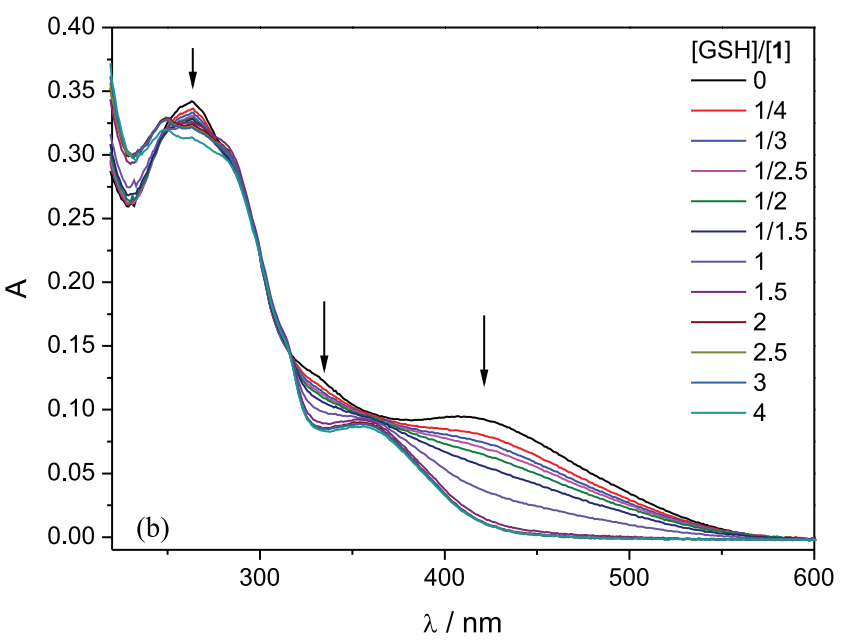

Figure 5. Addition of varying amounts of (a) Cys and (b) GSH to a solution of $\mathbf{1}$ in buffer Tris $(\mathrm{pH}=7.54)$ at $25^{\circ} \mathrm{C}$. 


\section{Effect of complex on cell viability}

In order to test the effect on cell viability, human MG-63 osteosarcoma cells were exposed to 1 . Cisplatin was used as a clinical reference. Figure 6 shows that 1 impaired the cell viability in the range of $10-100 \mu \mathrm{M}$, with statistically significant differences versus basal condition $(p<0.01)$. The half maximal inhibitory concentration $\left(\mathrm{IC}_{50}\right)$ value of $\mathbf{1}$ is $19.5 \pm 2.4 \mu \mathrm{M}$, suggesting a moderate anticancer activity of this complex as compared with other metal-based drugs reported for osteosarcoma treatment. ${ }^{14}$ It must be noted that several rhenium compounds showed similar $\mathrm{IC}_{50}$ values against cancer cells. ${ }^{15}$ In this case, no experimental evidence is presented to attribute the chemotherapeutic activity to the rapid reaction of the complex with GSH. However, there may be a link to these redox properties if we take into account the similar structure of $\mathbf{1}$ to the previously studied species ${ }^{4}$ of formula $\left[\mathrm{Re}_{2}(\mathrm{CO})_{6}(\mathrm{dip})_{2} \mathrm{~L}\right]\left(\mathrm{PF}_{6}\right)_{2}$ (dip = 4,7-diphenyl1,10-phenanthroline; $\mathrm{L}=4,4$ '-azopyridine), in which evidence has been obtained of chemotherapy via a mitochondria-to-cellular redox strategy and cell death via apoptosis. Besides, the chemotherapeutic activity could be related to the rapid reaction of $\mathbf{1}$ with GSH if we consider the role of this thiol in cancer progression. ${ }^{16}$ Our results point out that $\mathbf{1}$ is more active than cisplatin on MG-63 cells $\left(\mathrm{IC}_{50}=39 \pm 1.8 \mu \mathrm{M}\right) .{ }^{14}$

\section{DFT calculations}

Calculations at the DFT level were performed for species $\mathbf{1}$ and $\mathbf{1 H 2}$, with the purpose of having a better understanding of the nature of their molecular orbitals (MOs). As shown in Figure 7 and Tables S1 and S2 (SI

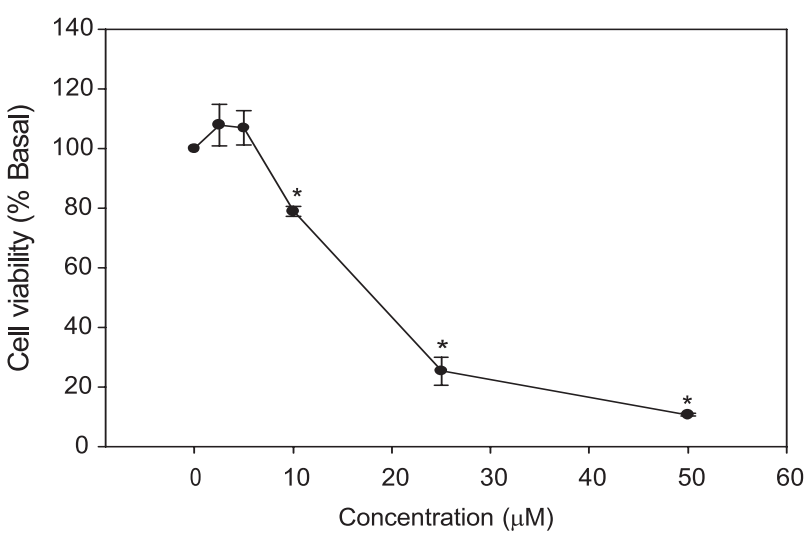

Figure 6. Evaluation of the mitochondrial succinate dehydrogenase activity by the MTT assay in MG-63 cells in culture. Osteosarcoma cells were incubated with different doses of $\mathbf{1}$ for $24 \mathrm{~h}$ at $37{ }^{\circ} \mathrm{C}$. After incubation, cell viability was determined by the MTT assay. Results are expressed as percentage (\%) of basal and represent the mean \pm SEM, $\mathrm{n}=18$. * Significant differences $v s$. control $(p<0.01)$.

section), there are considerable changes in the energy and composition of the frontiers MO's between both complexes. In 1, Figure 8 (left) shows that the LUMO is mainly centered in the azo bridge with a similar contribution of the bpy rings. Upon reduction and protonation of $\mathbf{1}$ to form $\mathbf{1 H 2}$, the LUMO is mainly centered on the bpy rings, as shown in Figure 8 (right). The HOMO is almost the same for both complexes, having a major contribution of the metallic center and a minor one from the $\mathrm{CO}$ groups. The lowest energy UV-Vis bands in $\mathbf{1}$ and $\mathbf{1 H 2}$ can thus be assigned to MLLCT transitions, with a higher energy gap for $\mathbf{1 H 2}$ than that for $\mathbf{1}$, as indicated in Figure 7, in consistency with the difference observed experimentally between the UV-Vis absorption maxima of both species (see Figure 5).
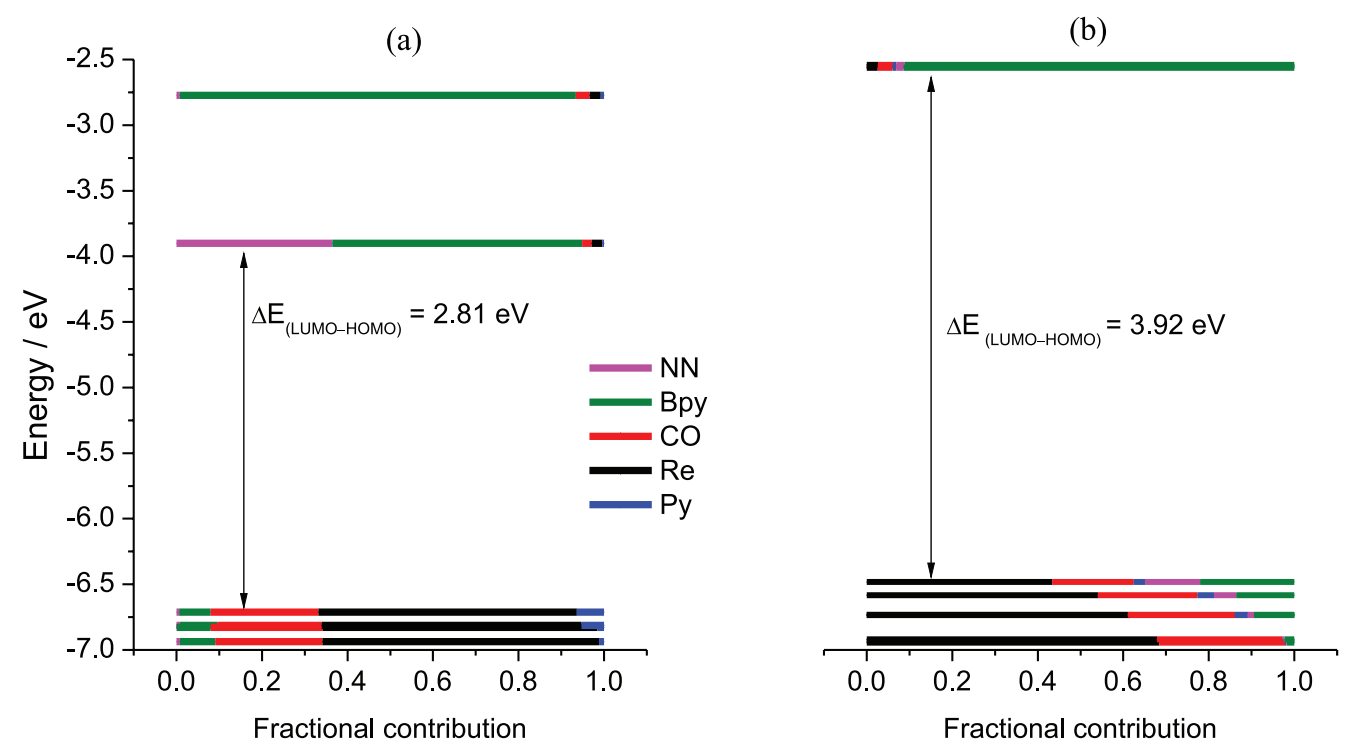

Figure 7. MO energy diagrams (a) for complex $\mathbf{1}$ and (b) for the doubly reduced and protonated product $\mathbf{1 H 2}$. 
(1)

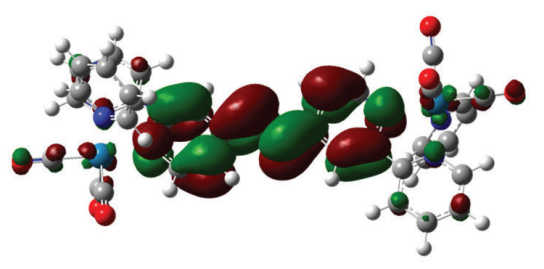

LUMO

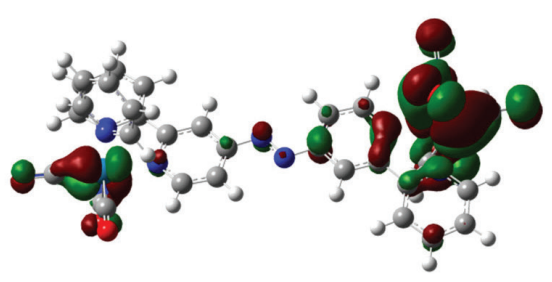

HOMO

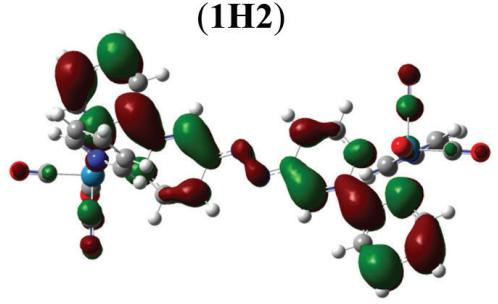

LUMO

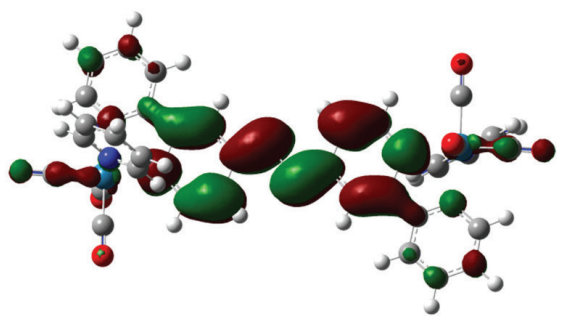

HOMO

Figure 8. Frontier MO's for $\mathbf{1}$ and $\mathbf{1 H 2}$.

\section{Conclusions}

A new symmetrical dirhenium complex with 4,4 "-azobpy as a bridging ligand has been prepared and characterized by spectroscopic and electrochemical techniques. Detection of Cys or GSH at the micromolar level can be accomplished by measuring the fast and considerable UV-Vis absorption changes that occur upon double reduction and double protonation of the complex with both thiol containing amino acids, which can be rationalized by DFT calculations. This complex exhibits a remarkable activity against osteosarcoma cell lines.

\section{Supplementary Information}

Supplementary information $\left({ }^{13} \mathrm{C}\right.$ NMR spectrum, two-dimensional ${ }^{1} \mathrm{H}-{ }^{1} \mathrm{H}$ COSY spectrum, two-dimensional ${ }^{1} \mathrm{H}-{ }^{13} \mathrm{C}$ HMBC spectrum, two-dimensional ${ }^{1} \mathrm{H}-{ }^{13} \mathrm{C}$ HSQC spectrum of $\mathbf{1}$ in $\mathrm{CD}_{3} \mathrm{CN} ;{ }^{1} \mathrm{H}$ NMR spectrum of $\mathbf{1 H 2}$ in $\mathrm{CD}_{3} \mathrm{CN}$; effect of chemical reduction on the cyclic voltammogramm of $\mathbf{1}$; calibration curves for Cys and GSH detection by reactions with $\mathbf{1}$; energies and compositions of MOs for $\mathbf{1}$ and $\mathbf{1 H 2}$ ) is available free of charge at http://jbcs.sbq.org.br as PDF file.

\section{Acknowledgments}

We thank CONICET (grant PIP-2015-098), UNT (grant PIUNT 26/D-620) and ANPCyT (grant PICT-2015-0553) for finantial support. P. O. A. thanks CONICET for a graduate fellowship. I. E. L. and N. E. K. are members of the Research Career (CONICET).

\section{References}

1. Li, G.-Y.; Liu, J.-P.; Huang, H.-Y.; Wen, Y.; Chao, H.; Ji, L.-N.; J. Inorg. Biochem. 2013, 121, 108.

2. Li, G.; Chen, Y.; Wu, J.; Ji, L.; Chao, H.; Chem. Commun. 2013, 49, 2040.

3. Zeng, L.; Kuang, S.; Li, G.; Jin, C.; Ji, L.; Chao, H.; Chem. Commun. 2017, 53, 1977.

4. Wang, F.-X.; Liang, J.-H.; Zhang, H.; Wang, Z.-H.; Wan, Q.; Tan, C.-P.; Ji, L.-N.; Mao, Z.; ACS Appl. Mater. Interfaces 2019, 11, 13123.

5. Abate, P. O.; Pourrieux, G.; Morán Vieyra, F. E.; Cattaneo, M.; Vergara, M. M.; Katz, N. E.; Polyhedron 2018, 149, 109.

6. Otsuki, J.; Sato, K.; Tsujino, M.; Okuda, N.; Araki, K.; Seno, M.; Chem. Lett. 1996, 25, 847; Otsuki, J.; Imai, A.; Sato, K.; Li, D.-M.; Hosoda, M.; Owa, M.; Akasaka, T.; Yoshikawa, I.; Araki, K.; Suenobu, T.; Fukuzumi, S.; Chem. - Eur. J. 2008, 14, 2709.

7. Abate, P. O.; Pourrieux, G.; Morán Vieyra, F. E.; Borsarelli, C. D.; Parella, T.; Vergara, M. M.; Katz, N. E.; Polyhedron 2019, 174, 114149 .

8. Frisch, M. J.; Trucks, G. W.; Schlegel, H. B.; Scuseria, G. E.; Robb, M. A.; Cheeseman, J. R.; Montgomery Jr., J. A.; Vreven, T.; Kudin, K. N.; Burant, J. C.; Millam, J. M.; Iyengar, S. S.; Tomasi, J.; Barone, V.; Mennucci, B.; Cossi, M.; Scalmani, G.; Rega, N.; Petersson, G. A.; Nakatsuji, H.; Hada, M.; Ehara, M.; Toyota, K.; Fukuda, R.; Hasegawa, J.; Ishida, M.; Nakajima, T.; Honda, Y.; Kitao, O.; Nakai, H.; Klene, M.; Li, X.; Knox, J. E.; Hratchian, H. P.; Cross, J. B.; Bakken, V.; Adamo, C.; Jaramillo, J.; Gomperts, R.; Stratmann, R. E.; Yazyev, O.; Austin, A. J.; Cammi, R.; Pomelli, C.; Ochterski, J. W.; Ayala, P. Y.; Morokuma, K.; Voth, G. A.; Salvador, P.; Dannenberg, J. J.; Zakrzewski, V. G.; Dapprich, S.; Daniels, A. D.; Strain, M. C.; 
Farkas, O.; Malick, D. K.; Rabuck, A. D.; Raghavachari, K.; Foresman, J. B.; Ortiz, J. V.; Cui, Q.; Baboul, A. G.; Clifford, S.; Cioslowski, J.; Stefanov, B. B.; Liu, G.; Liashenko, A.; Piskorz, P.; Komaromi, I.; Martin, R. L.; Fox, D. J.; Keith, T.; Al-Laham, M. A.; Peng, C. Y.; Nanayakkara, A.; Challacombe, M.; Gill, P. M. W.; Johnson, B.; Chen, W.; Wong, M. W.; Gonzalez, C.; Pople, J. A.; Gaussian 03, Revision C.02; Gaussian Inc., Wallingford, CT, USA, 2004.

9. Perdew, J. P.; Burke, K.; Ernzerhof, M.; Phys. Rev. Lett. 1996, 77, 3865.

10. O'Boyle, N. M.; Tenderholt, A. L.; Langner, K. M.; J. Comput. Chem. 2008, 29, 839.

11. Mosmann, T.; J. Immunol. Methods 1983, 65, 55.

12. Worl, L. A.; Duesing, R.; Chen, P.; Della Ciana, L.; Meyer, T. J.; J. Chem. Soc., Dalton Trans. 1991, 849.

13. Coe, B. J.; Foxon, S. P.; Pilkington, R. A.; Sánchez, S.; Whittaker, D.; Clays, K.; Van Steerteghem, N.; Brunschwig, B. S.; Organometallics 2016, 35, 3014.
14. Ruiz, M. C.; Kljun, J.; Turel, I.; Di Virgilio, A. L.; León, I. E.; Metallomics 2019, 11, 666; León, I. E.; Porro, V.; Di Virgilio, A. L.; Naso, L. G.; Williams, P.A. M.; Bollati-Fogolín, M.; Etcheverry, S. B.; J. Biol. Inorg. Chem. 2014, 19, 59; León, I. E.; Di Virgilio, A. L.; Porro, V.; Muglia, C. I.; Naso, L. G.; Williams, P. A. M.; Bollati-Fogolín, M.; Etcheverry, S. B.; Dalton Trans. 2013, 42, 11868.

15. Gantsho, V. L.; Dotou, M.; Jakubaszek, M.; Goud, B.; Gasser, G.; Visser, H. G.; Schutte-Smith, M.; Dalton Trans. 2020, 49, 35.

16. Traverso, N.; Ricciarelli, R.; Nitti, M.; Marengo, B.; Furfaro, A. L.; Pronzato, M. A.; Marinari, U. M.; Domenicotti, C.; Oxid. Med. Cell. Longevity 2013, 2013, 972913.

Submitted: January 6, 2020 Published online: May 11, 2020 